\title{
Türk Kamu Yönetim Sisteminde Dijital Dönüşüm
}

\begin{abstract}
Ahmet KARAÇORLU ${ }^{*}$
Öz: Eskiden bilgi ve haberleşme teknolojilerinin insanlara sunduğu imkânlar hayli sınırlıydı. Zamanla küresel evrim aracı olarak kullanılmaya başlayan bilgihaberleşme teknolojileri sayesinde imkânlar artarak evrende vazgeçilmez bir öğe haline gelmiştir. Dijitalleşmenin yaygınlaşması sayesinde teknolojik gelişmelerde oldukça popülarite kazanmış ve internet hayatımızın önemli parçası halini almaya başlamıştır. Bilhassa 2000'li yılların ilk çeyreğinden itibaren endüstri toplumundan bilgi toplumuna doğru hızlı bir evrim meydana gelmiştir. Bilgi-haberleşme teknolojilerinin, kamu ve özel teşebbüs kuruluşları üzerinde önemli etkileri olmuştur. Muhakkak, bu tesirden Türk Kamu Yönetimi de nasibini almıştır. Teknolojinin etkisiyle beraber, vatandaşların kamudan aldığ1 hizmetten beklentilerini değiştirmiştir. Bu beklentilere cevap vermek amacıyla kamu tarafindan hizmet taleplerinin daha hızlı ve ucuz bir biçimde karşılanması için bilgi-haberleşme teknolojilerinden faydalanılarak dijital uygulamalar geliştirilmiştir. Çalışma 2000'li yılların başından bugüne kadar, vatandaşlara etkili ve faydalı hizmet sunmak için dünyada hızla yürütülen dijital devlet ve dijital belediye uygulamalarının yanı sıra yerel katılımı artırma ve merkezî hükümetin bürokratik maliyetlerini ve yükünü hafifletme imkânları da sağlamaktadır. $\mathrm{Bu}$ çalışmada dijitalleşmenin Türk kamu yönetim sistemine etkisinden bahsedilip ardından e-devlet kavramı ve uygulması, e-belediye kavramı bunun yanında mahalli idarelerde e-belediye uygulamamaları yorumlanmaktadır. Çalışmanın sonuç ve değerlendirme kısmında ise dijitalleşme sayesinde kamu kurumlarının halka hizmet sunma noktasında ne tür imkânlar sağladığının değerlendirilmesi yapılmıştır.
\end{abstract}

Anahtar Kelimeler: Kamu Yönetimi, Mahallî İdareler, E-Devlet, EBelediye.

\section{Digital Transformation In Turkish Public Administration System}

Abstract: In the past, the opportunities offered by information and communication technologies to people were very limited. Thanks to information and communication technologies that have started to be used as a tool of global evolution over time, opportunities have increased and become an indispensable element in the universe. Thanks to the popularization of digitalization, it has gained considerable popularity in technological developments. Since the first quarter of the 2000s, there has been a rapid evolution from industry society to Information Society. Information-communication technologies have had a

* İstanbul Büyükşehir Belediyesi Halkla İlişkiler Uzmanı, İstanbul/Türkiye. e-mail: ahmetkaracorlu44@gmail.com

ORCID: 0000-0002-7587-2212

$\begin{array}{ll}\text { Geliş Tarihi: 11 Mart 2021 } & \text { Kabul Tarihi: 20 Mayis } 2021 \\ \text { Received: 11 March 2021 } & \text { Accepted: } 20 \text { May 2021 }\end{array}$

Bu makaleye atıf için / To cite this article: Karaçorlu, A. (2021). Türk Kamu Yönetim Sisteminde Dijital Dönüşüm. Medeniyet Araştırmaları Dergisi, 6(1), 163-178.

Doi: $10.52539 / \mathrm{mad} .894922$ 
significant impact on public and private enterprise organizations. Of course, the Turkish public administration has also received its share of this influence. With the influence of technology, it has changed the expectations of citizens from the service they receive from the public. In order to meet these expectations, digital applications have been developed by using informationcommunication technologies to meet service demands faster and cheaper by the public. From the beginning of the 2000s until today, digital government and digital municipal practices, which have been rapidly implemented around the world to provide effective and useful services to citizens, on the other hand, increase local participation and provide the opportunity to alleviate the bureaucratic costs and burden of the central government.

Keywords: Public Administrations, Local Administrations, E-Governmet, EMunicipality.

\section{Giriş}

Küreselleşme süreci ve bilgi toplumu, bilgiyi kullanabilmenin en geçerli yöntemlerini birlikte meydana getirmişlerdir. Bilgi-haberleşme teknolojisi ve internet, hemen her yerde haberleşmeyi ve ulaşımı kolaylaştırmıştır. Eski zamanlarda hayata geçirilmesi oldukça zor olan işler dijital uygulamalar vasıtasıyla kolaylaşmış; hizmet kalitesini, verimliliği ve etkinliği artırmış; kamusal giderlerde ve zamandan tasarruf edilmesini sağlamıştır. Hızla yayılan bilgi ve haberleşme teknolojileri, kamu idaresindeki "e-Devlet" ve "e-Belediye" kullanım alanlarını meydana getirmiştir. Söz konusu gelişmelerle birlikte devre uyum sağlayabilmek için teknolojik gelişmeleri izleme gerekliliği ön plana çıkmıştır. Kamu kuruluşlarında gerçekleştirilebilecek pek çok hizmet internet ortamında verilmeye başlanmıştır. Kamu idarelerinin önemli ve ihmal edilemez niteliğini meydana getiren mahallî idarelerin kamu hizmetinin sunumunda dikkate değer bir rolü vardır. Kamu faaliyet alanının sosyal görevleri ile ekonomik, sosyal ve kültürel yapısında meydana gelen değişimler, var olan kamu yönetim modelini de farklılaşmaya zorlamıştır.

Demokrasinin vazgeçilmezi olan ve nüfus artışıyla birlikte hızla gelişen mahallî idareler, mahallî gereksinimleri etkin bir biçimde vatandaşa sunmak için kendisini yenilemek ve var olan sıkıntılara çözüm üretmek amacıyla yeni planlamalar yapma ihtiyacı duymuştur. Türkiye'de mahallî idarelere yönelik 1980 yılından sonra yapılan önemli girişimlerle mahallî idareler daha etkili, faydalı ve vatandaş odaklı kurumlar hâline dönüştürülmeye çalışılmışıtır. Euygulamaların ortaya çıktığı 1990 yılında, haberleşme araçlarının ve internetin yayılmasıyla mahallî idareler alanındaki bu değişime ve dönüşüme dönük eylemlerin gerçekleştirilmesi eski zamana göre çok daha basitleşmiştir. Gerçekleştirilen çalışmaların meydana getirdiği sonuçların bazen olumlu bezen de olumsuz yanları ön plana çıkmaktadır. Dijital devir, vatandaşların demokratik haklarını ne şekilde kullanması gerektiği ve tavırları yönündeki değişimi gerçekleştirmektedir. Vatandaş, alınan kararlara katılma ve denetleme imkânına sahip olmaktadır. Yalnız, bunun için ulaşılabilir ve kullanılabilir olması da önemlidir.

$\mathrm{Bu}$ makalede, bilgi-haberleşme teknolojileri sayesinde ortaya çıkan dijital uygulamaların günümüzde kamusal hizmetlerdeki etkinliği ve verimliliği nasıl artırdığ 1 üzerinde durularak merkezî yönetim ile belediyelerin bu dijital uygulamalardan nasıl faydalandıkları incelenecektir. 


\section{Kamu Yönetiminde Dijital Dönüșüm}

Günümüzde ülkeler aralıksız dijital dönüşüme maruz kalmaktadırlar. Kișiler, șirketler ve iș kolları ile birlikte objeler de dijitalleșme yolunda hızla ilerlemektedirler. $\mathrm{Bu}$ dijital değişimle beraber kişilerin gündelik hayatları, çalışma şartları, alışkanlıkları ve değer yargıları da değişmeye başlamış; gündelik hayatın hemen her alanında esaslı dönüşmeler meydana gelmiştir. İnsanlar birbirleriyle zahmetsiz ve değişik biçimlerde haberleşme sağlamaya başlamış, özel teşebbüs çevrim içi (online) ticarete dönmüş, insanların alışveriş alışkanlıkları dijital alışverişe doğru evrilmiştir. Kamu sektörü de bu süreçten etkilenmiş, halk ve kamu kuruluşları arasındaki etkileşim yaygınlaşmış, kamu kuruluşları bazı kamusal hizmetlerini dijital ortama aktarmaya başlamıştır. $\mathrm{Bu}$ değişmeler öncelikle kamu kuruluşlarıyla halk arasındaki haberleşmenin internet, akıllı telefon ve sosyal medya aracılığıyla gelişmesi; kamu kuruluşlarının kamuyu bilinçlendirme kanallarını dijital ortama taşıması şeklinde gözlemlenmiştir. Eskiden kamu kuruluşlarına gidilerek alınan hizmetler arasında yer alan adli sicil kaydı, mezuniyet belgesi, nüfus kayıt örneği ile vergi ödeme gibi konularda idare ve mahallî idarelerde sosyal medya ve birçok ortamda politik katılımı sağlamak üzere çeşitli uygulamalar geliştirilmiştir. Kamu kuruluşları, vatandaşlar ve objelere yönelik sonsuz verinin işlenebilir ve birtakım amaçlarla kullanılabilir duruma getirdiği büyük veri; kamu idarecileri ve kamu bürokratları için daha iyi politikalar geliştirmede de aracı olmuştur (Gül, 2018: 13).

Türk kamu yönetiminde özellikle 1990'lardan sonra küreselleşmenin de tesiriyle çağdaşlaşma ve reform çerçevesinde gerçekleştirilen iyileştirmelerin başını kamu yönetiminde meydana gelen dijitalleşme çekmektedir. $\mathrm{Bu}$ değişimde devletin devamlı kendisini yenileyen, günün koşullarına göre politik, iktisadi ve sosyo-kültürel olarak değişimler geçiren devingen bir toplum olmasının da payı büyüktür. Son zamanlarda özellikle dünyada internet kullanımının artması, bilgi-haberleşme teknolojilerinde meydana gelen durumlar, akıllı cep telefonu ve mobil uygulamaların yaygınlaşması kamu yönetimini de büyük oranda etkilemiştir (Peker, 2015: 172).

Söz konusu bilgi-haberleşme teknolojilerinin özel teşebbüslerce başarılı bir biçimde kullanılmasının da etkisi büyük olmuştur. Bilgi-haberleşme teknolojilerinde görülen hızlı değişimler devletin varlık nedeni olan eğitim, sağlık, güvenlik ve ulaşım benzeri kamu hizmetlerine dönük vatandaşların devletten beklentileri ile birlikte devlete karşı tavırlarını da başkalaştırmıştır (Ac1lar, 2012: 125). Bu durum halkın devletten, e-Devlet benzeri dijital uygulamaların daha çok kullanılmasına yönelik talepte bulunmasına yol açmıştır. Bunun sonucunda da devletler internet kullanımını teşvik etmek, eDevlet uygulamalarını artırmak, bilgisayar kullanımını yaygınlaştırmak için bazı planları ve uygulamaları hayata geçirmeye başlamışlardır (Şahin, 2007: 162).

\section{Mahallî İdarelerde Dijital Dönüşüm}

Hızla evrimleşen, gelişen ve şehirleşen bir dünyada yaşamaktayız. Özellikle 21. yüzyılın başından itibaren insanların hayatlarında hayal edilemeyecek düzeyde önemli değişmeler meydana gelmiştir. Bu değişmeler, vatandaşların yaşadıkları yerlerde toplumsal, iktisadi, yönetimsel ve kültürel bir etkileme ortaya çıkarmış; vatandaşların hizmet alanları konusundaki talepleri de 
gitgide farklılaşmıştır. Meydana gelen bu değişmeler, kent idarelerini daha etkin bir hâl almaları hususunda mecbur bırakmıștır (Bulut, 2000: 1). Kamu yönetiminde bilgi ve haberleşme teknolojilerinin evrimi idare biçimini değiştirmiştir (Kaypak, 2009: 215). Meydana gelen bu durumlara ayak uydurabilmek için kamu hizmetleri değişik metotlar ve teşkilatlanmalar ile gerçekleştirilmeye çalışılmıştır. Bu teşkilatlanmalar, kamusal hizmetlerin alanı ve nitelikleri bakımından farklılık gösterebilmektedir (Toprak, 2006: 3). Mahallî idareler, vatandaşa kamusal hizmetleri en iyi biçimde aksettirebilmek için bu yolu izlemişlerdir. Kamusal hizmetlerin sunulmasında ve kamu kaynaklarından yararlanılmasında mahallî idarelerin öneminin gitgide artığ 1 da söylenebilir (Eren, 2011: 89). Mahallî idareler pek çok hizmetin halka sunulması konusunda hızlılık ve olanak sağlamışlardır (Keleş, 2006: 26).

Bir devletin sosyal yönden büyümesi, mahallî idarelerin varlığı ve düzenlenmesiyle yakından ilgilidir (Henden, 2005: 50). Mahallî idarelerin esas amacı, kaynakları etkili ve faydalı bir biçimde kullanarak vatandaşa daha hızlı, uygun ve nitelikli hizmet sunmaktır (Belli, 2016: 17). Bu amacı gerçekleştirmek için dijital devrin getirdiği yenilik olan internet ve bilgi teknolojilerinden yararlanmaya çalışmıştır. Vatandaşın en fazla başvurduğu kuruluşların başında gelen mahallî idareler, hizmet alanlarını büyüterek etkinliklerini artırmak ve hizmet kalitelerini yukarı çekmek için bilgi teknolojilerine yatırım yapmaktadır (Kaypak, 2010: 15).

Haberleşme sistemlerinin gelişmesiyle birlikte aktif biçimde kullanılmaya başlanan dijital devir elemanlarından akıllı telefon, tablet, dizüstü bilgisayar benzeri haberleşme araçları ve internetin yayılmasıyla birlikte vatandaşlar yurt içi ve yurt dışı verilere hızlı bir biçimde erişebilme olanağ bulmuşlardır. Teknolojik gelişmeler sonucunda meydana gelen dijital devirde, internet üzerinden bilgilere rahatça erişilebilmesinin bazı yararları vardır. Mahallî idarelerin etkili, açık ve katılımcı bir idare anlayışını benimsemesinin önü açılmıştır. Dijital devir öncesi kendi içerisine kapanmış bir biçimde evrimini tamamlamaya çalışan mahallî idareler, dijital devir sonrası hem kendi icraatları hem de dünyada uygulanan mahallî idare biçimleri hakkında o bölgeye gitmeden internet aracılığıyla ayrıntılı verilere erişebilmiş̧lerdir. Bu durum mahallî idarecilere, kendi yaşadıkları yerele uygun yönetim biçimlerini gerçekleştirebilme ve sonuçlarına ilişkin bilgi edinebilme konusunda yardım etmiş, sınırlı kaynaklarını daha etkili ve yararlı biçimde kullanımının ne şekilde sağlanacağı hakkındaki değişime de katkı sağlamıştır.

Mahallî idarelerde dijital devir ya da dijital dönüşüm ile birlikte pek çok yenilik meydana gelmiştir. Bu yeniliklerden birkaçı şu şekildedir (Henden, 2005: 59):

- Mahallî idare kurumlarının karar organı olan meclislerin karar alma aşamalarına vatandaşların katılmasına imkân tanımış ve alınan kararları halkın hızlıca öğrenmesini sağlamıştır.

- Mahallî idarelerin karar mercii eliyle makasta en uygun kesinlikte ve zamanında kararlar alınmasına imkân tanımıştır.

- Mahallî idareleri tarafsızlık, şeffaflık ve hesap verebilirlik kriterlerine göre tavır almaya zorlamıştır.

- Vatandaş odaklı hizmet modelini benimseyen mahallî idarelerin, süratli ve çabucak çok fazla bilgi yığınına erişmesine olanak tanımıştır. 
- Kuruluşların bilişim (enformatik) teknolojilerini iyi seviyede işleyebilen kabiliyetli elemanlar bulmasına önemli yararları olmuştur.

- Mahallî idarelerin, görevlendirmiş olduğu elemanların verimliliğini takip etmesi kolaylaşmış ve eleman görevlendirme ölçümlemesine katkı sağlamıştır.

- E-mail aracılığıyla halka, çeşitli taleplerini iletebilme firsatı tanımıştır.

- E-Belediye uygulaması, vatandaşın hayatını kolaylaştıran uygulamaların oluşturulmasının yolunu açmıştır.

- E-Belediye uygulaması bireylere kendilerine ait su, doğal gaz, ceza ve vergi borçlarını öğrenebilme ve ödeyebilme imkânı sunmuştur.

- Mahallî idarecilerin düzenlemesi zorunlu raporları hızlandırmasında ve gerekli bilgilere erişmesinde kolaylık sağlamıştır.

- Mahallî idare kuruluşlarına ait kurumsal verilerin saklanması ve toplanmasında önemli kolayliklar getirmiştir.

- Güncel ve gerçek bilgilerin hızlı bir şekilde vatandaşa ulaştırılmasını sağlamıștır.

- Mahallî idarelere problemlerin çözümünde işlevsellik tanımıştır.

Mahallî idarelerdeki dijital değişim ümidini, "iyimser ümidini paylaşanlar" ve "kötümser-şüpheci ümidini paylaşanlar" olmak üzere ikiye ayırmak mümkündür. Bunlardan iyimser ümidini paylaşanlar bilgi teknolojilerinin etkili ve faydalı olduğunu, hesap verebildiğini, demokratik katılımın çoğalacağını ifade etmektedirler. Kötümser-şüpheci ümidini paylaşanlar ise bilgi teknolojilerinin vatandaşı denetleyen bir vasıta olduğunu, kişisel yaşama karışmasının engellenmesi gerektiğini savunmaktadırlar. $\mathrm{Bu}$ durum, onları korkutmakta ve bilgilerin kötüye kullanılacağını düşündürmektedir (Yıldız, 1999: 45).

Dijital devir yardımıyla oluşan değişme, devingen bir sürecin varlığını meydana çıkarmaktadır (Yıldırım, 2004: 49). Mahallî idare sınırları içerisinde ikamet eden, çalışan, işsiz, memur ve öğrenci gibi hemen herkes kişisel bilgisayarlarından, okul, kütüphane ya da kamusal alanlardaki mahallî istasyonlardan, mahallî idarelerle alakalı her türlü belgeye erişebilme; mahallî idare personelleri ve başka vatandaşlarla haberleşebilme, çevrim içi konferanslar ve sohbet kanalları vasıtasıyla mahallî idarelerin sıkıntılarına ilişkin dizgelerde bulunabilme, birtakım belge ve raporlanı mahallî idarecilere sunulabilme imkânlarına erişmişlerdir. Böylece halk, akla gelebilecek her konuda birbirleriyle etkileşimde bulunup ortak sıkıntılarını dile getirerek görüş bildirebilmektedir (Y1ld1z, 1999: 146).

Dijital devirle beraber, vatandaşa mahallî idarelere katılma ve bilgi edinme imkânı verilmiştir. Dijital devirle başlayan katılım ve mahallî idareler denildiğinde akla ilk gelen il özel idaresi, belediyeler ve taşranın dijital devir öncesi ve sonrasi durumunun nasil olduğudur.

\section{Dijital Dönüşüm ile Ortaya Çıkan Katılım}

Katılım, iştirak etmek fiiline dayanmaktadır. İştirak edilen karar veya eylem korunmalıdır. Katılım, "dâhil olma" ya da "müdahil olma" terimleri ile anlamdaştır (Karkın, 2011: 60). Kamu yönetimindeki katılım ise, vatandaşlarla ilgili uygulamalarda karar mercileri tarafından alınan kararlara halkın dâhil olması şeklinde açıklanabilmektedir. Kamu idaresinde hem vatandaşın yönetime 
katılması hem de kamusal hizmetlerin halka sunulması konusunda üstlendikleri vazifeler sebebiyle vatandaşın yönetime katılımının ilk aşaması olarak kabul edilmektedir (Toprak, 2014: 36).

Günümüzde mahallî idareler tarafindan gerçekleştirilen kamusal hizmetler, küreselleşme ve teknolojik gelişmelere bağlı olarak devamlı değişim ve büyüme yönünde bir yol izlemektedir. Biçimlenmeye başlayan sistem içerisinde, mahallî idarelerin ve kentlerin ön plana çıkmasıyla birlikte idare kavramı önem kazanmıştır (Kaypak, 2009: 216). Bu sebeple, idari anlamda kararların alınması sürecinin daha çabuk ve etkin olması isteği öne çıkmış ve kararların alınması süreci kolaylaşmıştır. Küreselleşmeyle birlikte ortaya çıkan dijitalleşme sonrasında vatandaşın yönetime katılımı önemli seviyelere ulaşmıştır. Haberleşme ve bilişim alanlarında meydana gelen evrimin yerelde katılıma olumlu etkisi olmuştur. Yerelde katılımın artması sayesinde, mahallî idareciler kararlarını hem çabuk hem de etkin bir biçimde uygulayabilmişlerdir.

Yerelde katılım, mahallî idarelere ait web sitelerine vatandaşın internetten ulaşması ve gerekli bilgilere erişmesi, ulaşılan bilgilerle ilgili düşüncelerini, fikirlerini ve tavsiyelerini yine site içerisinde bulunan Beyaz Masa bölümüne yazabilmesi sağlanmıştır. Mahallî idarecilerin ise bu bilgileri inceleyip vatandaşın talep ve şikâyetlerine dönük kararlar alması beklenmiştir. Vatandaşlara kamuya yönelik talep, öneri ve şikâyetlerini T.C. Cumhurbaşkanlığı İletişim Merkezi (CİMER) üzerinden iletebilme imkânları verilmiştir. Beyaz Masa ve CIMER uygulamaları "kamu-vatandaş ilişkisini güçlendirmek" bağlamında dijitalleşme sayesinde gerçekleşmiştir.

Bu kapsamda e-Devlet ve e-Belediye hizmetleri, katılımcı ve şeffaf idare imkânı sunmaktadır. Mahallî idarelerce veya kamu kuruluşlarınca alınan karar metinleri, bakanlık hizmetleri, kamu ihaleleri, ihale şartları ve teklifleri ile kentsel planlama benzeri pek çok konu bu dijital uygulamalar aracığıyla sağlanmaktadır. Bu katılımın temelinde, dijitalleşme dışında kamuda vatandaş odaklı yönetim anlayışının benimsenmesi de yatmaktadır. Tüm bu katılım yolları, halkla ilişkiler esas vazifesi çerçevesinde şekillenmektedir. Kamu idaresindeki halkla ilişkiler, yetki ve yükümlülükleri dâhilinde gerçekleştirdikleri eylemlere yönelik vatandaşa tek taraflı açıklama yapmak veya vatandaştan geri bildirim alma noktasında şikâyet, talep ve önerileri almak biçiminde hayata geçirilmektedir. Kamu yönetiminin dijital nimetleri olarak açılanan araçları kullanarak devletine sahip çıan hassas bir toplum yaratmayı ve vatandaş katılımını artırmayı amaçlamıştır.

\section{Türkiye'de İnternetin Yaygınlaşması}

İnternet, dijitalleşmeyle ortaya çıkan yeniliklerden birisidir. Türkiye'ye internet 1993 yılında gelmiştir. Üniversiteler aracıllı̆ı̀la ülkeye yayılan internet kullanımı, üniversite öğrencilerinin yoğun ilgisine rağmen büyük şehirlerdeki orta ve üst zümredeki kullanıcılar ile kamu ve özel teşebbüsteki birtakım kuruluşlarla sınırlı kalmıştır. 1998'de Türkiye'de internete bağlı 44 bin bilgisayar ve yaklaşık 7 bin web sitesi, 200 ile 300 bin arasında kullanıcı olduğu söylenmektedir (Yıldız, 1999: 149).

Türkiye Cumhuriyeti Ulaştırma ve Altyapı Bakanlığı Bilgi Teknolojileri ve İletişim Kurumu web sitesinden alınan bilgiye bakılarak Türkiye'de 2002 'den beri bilgi ve haberleşme teknolojilerine yapılan büyük yatırımlar sayesinde Uluslararası Telekom Birliği (ITU) verilerine göre 2002 öncesinde 
internet kullanıcısı sayısı yaklaşık 2,5 milyon iken son 18 yılda \%1900 artarak yaklaşık 82 milyon nüfusun 63 milyonu kesintisiz internete bağlanabilmektedir (https://internet.btk.gov.tr/istatistikler, t.y.).

Dijital pazarlama ajansı "We are Social Hootsuite" ortaklığıyla hazırlanan "Djital in 2020 Global Overview" raporunu web sitesinde yayımlamıştır. 244 ülkeden elde edilen verilerle hazırlanan 247 slaytta dijitalleşmenin ve internetin evrimi ile alakalı güncel verilere yer verilmiştir. Dijital Global in 2020 Overview raporunda Türkiye ile alakalı verilerden bahsetmeden önce incelemedeki göze çarpan sonuçlara değinmek gerekir. Yayımlanan slaytta (https://wearesocial.com/digital-2020, t.y.):

- 8 milyar nüfusa sahip dünyada 4,4 milyar insanın en az 1 adet cep telefonu kullandığ

- Dünya genelinde 4 milyar insan internet kullanmaktadır.

- İnternet kullanan 4 milyar insanın \%0,04'ü yani 1,7 milyonu iş amaciyla interneti kullanmaktadır.

- 4 milyar internet kullanıcısının 3,1 milyarı sosyal medya kullanmaktadır. $\mathrm{Bu}$ insanların yaklaşık 1,4 milyarı günde 8 saatini Twitter, Facebook, Instagram benzeri sosyal medya araçlarında geçirmektedir.

- Dünya genelinde 1,5 milyar insan akıllı cep telefonları üzerinden internete ulaşmaktadır.

- Dünyada en çok ziyaret edilen web sitesi 3,3 milyar tıklanmayla Google, ardından 2,4 milyar tıklanmayla YouTube olmuştur.

Dijital Global in 2020 Overview raporunda Türkiye ile ilgili veriler incelendiğinde dikkat çekici sonuçlardan bahsetmek gerekir. Yayımlanan slaytta (https://wearesocial.com/digital-2020, t.y.):

- 82 milyon nüfusa sahip Türkiye'nin \%75'i yani 57 milyon insan internet kullanmaktadir.

- 57 milyon internet kullanıcılarının \%71'i yani 40 milyonu aktif sosyal medya kullanicisidir.

- Türkiye'de 15-65 yaş aralığındaki insanlar günde yaklaşık 6 saat internette vakit geçirmektedir.

- Türkiye'de en fazla tıklanan internet siteleri arasında YouTube, Facebook ve Twitter ilk üç sırayı almaktadır.

- Türkiye nüfusunun \%53'ü yani 43 milyon insan en az 1 adet akıllı cep telefonu kullanmaktadır.

- Türkiye'de günlük 18 milyon insan interneti iş amacıyla kullanırken 39 milyonu ise sadece medyayı takip etmek için kullanmaktadır.

Görüldüğü üzere yapılan incelemelerde interneti 1998'de 200-300 bin arasında kullanan varken 2020 yılında bu sayı 57 milyona çıkmıştır. Akademisyenlere göre bu sayının daha da artacağı öngörülmektedir.

\section{Dijitalleşmede E-Devlet Uygulaması}

Günümüzde toplum yapısı bilgi devrinden dijital devre geçmiştir. Dijital devir iktisadi ve sosyolojik olarak bilgi ve tecrübenin teknoloji aracılığıyla artması, teknolojinin bütün sosyal alanları içermesi, toplumları değiştirerek büyütmesi, bilgiyi çabucak paylaşması, olaylara hızla yön vermesi ve ülkelerin tarih boyunca katettiği gelişim mesafesini çok daha süratli yol 
almasıla ifade edilen bir devirdir (Ineconomics, 2019). Dünyada meydana gelen dijital değişimden en fazla etkilenen kuruluşların başında kamu idaresi ve mahallî idareler gelmektedir. Kamu idaresinde dijital uygulamaların kullanım oranının artması, devletin tekrardan oluşum sürecine girme zorunluluğunu meydana getirmiştir. Bu bağlamda kamu yönetiminin tekrardan oluşturulması konusunda son zamanlarda çok fazla çalışma ve inceleme hayata geçirilmeye başlanmıştır. Bunlar arasında yer alan e-Devlet uygulaması bu incelemelerden biri olarak meydana gelmiş ve önem kazanmıştır. Kaynaklarda "dijital devlet", "akıllı devlet" olarak da ifade edilen e-Devlet olgusu bilimsel olarak ilk defa Amerika Birleşik Devletleri tarafından kullanılmıştır (Akcagündüz, 2013: 128).

Dünyada gerçekleştirilen kamu yönetimi ıslahatlarının değişmez bir parçası olarak isimlendirilen e-Devlet kamuya ilişkin bilgi ve hizmetlerin yerine getirilmesi, halka sunumu esnasında devletin işlevleri ile ilgili etkileşimlerin dijital ortama aktarılması ve bilgi-haberleşme teknolojilerinin kamu yönetiminde kullanılması biçiminde ifade edilmektedir (Çarıkçı, 2010: 98). Bir başka tanımda ise e-Devlet, bilgi-haberleşme teknolojileri vasıtasıyla devletin sunmuş olduğu hizmetlerin halka yakın, daha etkili, hızlı ve açık bir biçimde toplumun bütün paydaşlarına en az maliyetle dijital ortamda sunulması olarak açıklanmaktadır (İşleri, 2005: 40).

Kamu yönetiminde dijitalleşmeyle ilgili çalışmalar son zamanlarda yükselen bir ivme yakalasa da bu çalışmaların temellerinin 1990'ların son çeyreğinde atılmaya başlandığ 1 söylenebilir (Kaya, 2017). Avrupa'da Avrupa Komisyonu, Türkiye'de Kalkınma Bakanlığının e-Devlet faaliyetleri, "dijital devlet" adı altında sunulmuştur. 1998'de Avrupa Komisyonu dijitalleşmenin kamusal hizmetlerde nerelerde ve ne şekilde kullanılacağ 1 konusunda bir tablo yayımlamıştır. Söz konusu tablo şu şekildedir:

Tablo 1. Avrupa Komisyonunca Kamusal Hizmetlerde Dijitalleşme

\begin{tabular}{|c|c|c|c|}
\hline & Bilgilendirme Hizmetleri & Haberleşme Hizmetleri & Çevrim İçi İşlemler \\
\hline $\begin{array}{l}\text { Günlük } \\
\text { Hayat }\end{array}$ & $\begin{array}{l}\text { Eğitim } \\
\text { Sağlık } \\
\text { Ulaşım } \\
\text { Çevre } \\
\text { Kültür }\end{array}$ & $\begin{array}{l}\text { Danışmanlık } \\
\text { İhale İlanları }\end{array}$ & $\begin{array}{c}\text { Randevu Hizmetleri } \\
\text { Talep, Şikâyet ve } \\
\text { Öneri Hizmetleri }\end{array}$ \\
\hline $\begin{array}{l}\text { Uzaktan } \\
\text { Katılım }\end{array}$ & $\begin{array}{c}\text { Kamu Hizmetleri Rehberi } \\
\text { Yönetimsel Süreç } \\
\text { Kılavuzu } \\
\text { Kamu Kayıtları } \\
\text { Kamusal Kayıtlar }\end{array}$ & $\begin{array}{c}\text { Kamu Personellerine } \\
\text { İlişkin E-posta } \\
\text { Hizmetleri }\end{array}$ & $\begin{array}{c}\text { Dilekçelerin Dijital } \\
\text { Ortamda } \\
\text { Doldurulması }\end{array}$ \\
\hline $\begin{array}{l}\text { Siyasal } \\
\text { Katılım }\end{array}$ & $\begin{array}{c}\text { Kanuni Düzenlemeler } \\
\text { Meclis Toplantı Kararları }\end{array}$ & $\begin{array}{c}\text { Politik Konularda } \\
\text { Müzakere } \\
\text { Siyasetçilerle E-posta } \\
\text { Gönderme }\end{array}$ & $\begin{array}{l}\text { Halk Oylaması } \\
\text { Seçimler } \\
\text { Anketler }\end{array}$ \\
\hline
\end{tabular}

Kaynak: Avrupa Komisyonu, 1998.

Tablo 1'de görüldüğü üzere kamu yönetiminde dijitalleşmenin şimdilerde geldiği noktanın temelleri 1990'ların son çeyreğine dayanmaktadır. Günlük hayattaki dijital kamu yönetimine dair tahmin edilenlerin hepsi gerçekleşmekte ve bununla birlikte çevrim içi tahsilat, çevrim içi yüz yüze görüşme vb. gelişmiş hizmetler de artık verilmektedir. Uzaktan katılımda, kamu 
personelleri ile haberleşme yalnızca e-posta ile kısıtlı kalmamış birtakım yeni geliştirilen platformlarla da hizmet verilmeye başlanmıştır. Kamu hizmetleri ile ilgili dilekçelerin dijital ortama yüklenmesi sayesinde vatandaşın herhangi bir konuda devlet veri tabanında bulunan bilgilere hızlı ve şeffaf ulaşımı sağlanmıştır. Siyasal katılımda en önemli husus dijital ortamda halk oylaması ve seçimlere katılım özellikle gelişmiş ülkelerde uygulanmaya başlanmıştır.

Kamu yönetimi dijitalleşen yenilikçi kamusal hizmetlerin şeffaf, katılımc1, geleceğe dönük, özelleştirilmiş, müşterek ve koşullara hassas kriterler doğrultusunda büyümesi gerektiği vurgulanmaktadır. Kamu yönetiminde dijitalleşme sürecini inceleyen araştırmacılar, dijital devletin kamusal hizmetlerinin geçirdiği evreleri şu şekilde ifade etmektedir:

Tablo 2. Dijital Devletin Evreleri

\begin{tabular}{cc}
\hline Safhalar & Kullanım Durumu \\
\hline Dijitalleşme & Teknolojinin Kamu Yönetimine Girişi \\
Transformasyon & Teknoloji Tesiri İle İdari Teşkilatlanma \\
Entegrasyon & Teknoloji Tesirinde Kamu İdarecileri \\
\hline
\end{tabular}

Kaynak: Bertot, 2016.

Tablo 2'de görüldüğü üzere kamu yönetiminde dijital devletin üç temel evresi vardır. $\mathrm{Bu}$ evreler kısaca dijitalleşme, transformasyon ve entegrasyondur. $\mathrm{Bu}$ evreler aracıllı̆ıyla dijitalleşme kamu yönetimine girmiş, teknolojik uygulamalardan faydalanılmaya başlanmış ve ardından da idari olarak teşkilat yapısını değiştirmesi, bilgi-haberleşme teknolojileri aracılığıyla kamuda yeni birimlerin açılması, son olarak dijitalleşme ile kamu idarecileri teknolojik araçları kullanarak kitlelere ulaşması sağlanmıştır.

Bu kapsamda e-Devlet geleneksel devletin devamı değildir, tam tersine devletin yapısal ve fonksiyonel olarak değişimini kapsayan örnek bir uygulamadır (Delibaş, 2010: 105). Ayrıca e-Devlet halkın hizmet alabilmek için kamu binasına gitmesi yerine, devletin halkın ayağına gelmesini sağlayan bir uygulamadır (Yılmaz, 2019: 510). Bunların yanı sira e-Devlet uygulamaları hizmet sunumu haricinde insan kaynaklarının, iş akışının ve hizmetten faydalanan halkın kabiliyetlerinin en yüksek noktaya çıkarılarak yorumlanmasını sağlayan bir fikri de kapsamaktadır (Balc1, 2013: 267). Öte taraftan e-Devlet benzeri dijital uygulamalar yalnızca devletlere saygınlık kazandıran veya giderleri azaltan bir kamusal hizmet sunum biçimi değildir. Buna ilaveten şeffaf, eleştirilebilir, katılımcı ve etkin bir kamu yönetim modelini de gerektirmektedir. Bu bakımdan gerek kamusal hizmetleri alan halk tarafindan gerekse hizmeti veren kamu idareleri tarafindan vakit, kaynak ve eleman tasarrufu sağlayarak maliyetlerin en aza indirgenmesine, hizmet sunumunun hızlandırılmasına, hizmete ulaşımın daha mükemmel ve etkili olmasına da katkıda bulunmaktadır. Dijitalleşme daima kendisini tazeleyerek devamlı değişen, sonsuz bir süreçtir. E-dijitalleşmenin komplike yapısı, onun hayata geçirilmesini birbirini tamamlayan birtakım süreçlerden oluşturmaktadır (Oğurlu, 2010: 30). 
Tablo 3. Klasik Devlet ile E-Devlet Karșılaștırılması

\begin{tabular}{cc}
\hline Klasik Devlet & E-Devlet \\
\hline Etkisiz vatandaş, yönetimin istekleri & Etkin vatandaş, yeni kamu yönetişimi \\
Evraka dayalı, yüz yüze iletişim & Dijital ve çevrim içi iletişim \\
Dikey teşkilatlanma ve hiyerarşi & Yatay teşkilatlanma ve ağ oluşumu \\
Görevli cevabı & SMS, E-mail, çağrı merkezi \\
Vatandaş esaslı denetim & Öz devimli denetim \\
Monotip hizmet, uzayan süreçler & Başkalaştırılmış hizmet, süratli süreç \\
Artan işlem maliyetleri & Azalan işlem maliyetleri \\
Milliyetçilik & Ulusalcıllk \\
Örtülü devlet & Şeffaf devlet \\
\hline
\end{tabular}

Kaynak: Yurtay, 2015: 1.

Dünya çapında e-Devlet uygulamasının oluşturulmasının pek çok sebebi vardır. $\mathrm{Bu}$ sebeplerden biri de klasik devlet modelinde görülen değişmelerdir. Başka bir ifadeyle geleneksel kamu idaresine egemen olan merkeziyetçilik, kapalılık, bürokratik zümre benzeri nedenler kamu yönetiminde bazı arayışları yanında getirmiş ve bu durum karşısında kamu yönetiminde yeniden örgütlenmeye duyulan gereksinim e-Devlet uygulamasının meydana gelmesini sağlamıştır. Dünya çapında bilime dayalı üretime başlanması, dijitalleşmenin yaygınlaşması ve bunun neticesinde bilgi iletişim teknolojilerinin hizmet sunumunda kolaylık sağlaması, hız kazandırması, şeffaflık sağlaması, katılımı artırması, güven vermesi ve ucuz olmasının yanı sıra etkin bir halk, çeşitlendirilmiş hizmet üretme, halk katılımı, dijital haberleşme ve şeffaf devlet politikasını meydana getirmiştir (Pektaş, 2011: 69).

Birleşmiş Milletler tarafindan 2001'den günümüze kadar yaklaşık iki senede bir ülkelerin dijital devlet gelişmişlik seviyesini tespit etmek için hazırlanan raporda kamu yönetiminin etkinliğini, şeffaflığı ve verimliliğini artırmak maksadıyla bilgi ve haberleşme teknolojilerinin kullanımının sistemli bir ölçümlemesi sunulmaktadır. 2020'de Birleşmiş Milletler e-Devlet Gelişmişlik Endeksi'nde Türkiye 193 ülke arasında Çevrim İçi Hizmet Endeksinde 22. sıraya, e-Katılım endeksinde ise 23. sırada yer almıştır (https://cbddo.gov.tr, t.y.).

Tablo 4. Türkiye'nin Dijital Gelişmişlik Endeksi

\begin{tabular}{cccccc}
\hline Yıl & Ülke Sayısı & $\begin{array}{c}\text { E-Devlet } \\
\text { Gelişmişlik } \\
\text { Endeksi }\end{array}$ & $\begin{array}{c}\text { Cevrim İçi } \\
\text { Hizmet } \\
\text { Endeksi }\end{array}$ & $\begin{array}{c}\text { Haberleşme } \\
\text { Altyapı } \\
\text { Endeksi }\end{array}$ & $\begin{array}{c}\text { İnsan } \\
\text { Kaynağı } \\
\text { Endeksi }\end{array}$ \\
\hline 2020 & 193 & $53(0,7718)$ & $22(0,8588)$ & $79(0,62280)$ & $52(0,8287)$ \\
2018 & 193 & $53(0,7112)$ & $27(0,8889)$ & $89(0,4298)$ & $45(0,8148)$ \\
2016 & 193 & $68(0,5900)$ & $67(0,6014)$ & $88(0,3775)$ & $48(0,7910)$ \\
2014 & 193 & $71(0,5443)$ & $53(0,5591)$ & $86(0,3605)$ & $95(0,7133)$ \\
2012 & 193 & $80(0,4641)$ & $82(0,4641)$ & $80(0,3478)$ & $107(0,7726)$ \\
\hline
\end{tabular}

Kaynak: Türkiye Cumhuriyeti Cumhurbaşkanlığı Dijital Dönüşüm Ofisi, 2020.

\section{Dijitalleşmede E-Belediye Uygulaması}

Belediyeler kamusal hizmet sunumunda vatandaşa en yakın kurumlardır. $\mathrm{Bu}$ nitelik, kamu hizmeti sunma noktasında mahallî idarelere halkın aşırı başvurusunu gerekli hâle getirmektedir. Belediyeler de yerel halktan gelen bu başvuruları hızla ve daha az maliyetle yanıtlamak amacıyla hizmet 
imkânlarını ve niteliklerini yükseltmek için dijital teknolojilere yatırım yapmaktadırlar. Dijital devlet uygulamalarının belediyelere uyarlanmış hâli olan e-Belediye, belediyelerin vazife ve hizmetlerinin dijital ortamda çevrim içi olarak halka sunulması olarak ifade edilmektedir (Ulusoy, 2013: 273). Diğer bir ifadeyse dijital tabanlı kentsel idare sürecinin en önemli uygulamalarından biri olan e-Belediye, kamusal hizmet sunumunun dijital ortamda halkın hizmetine sunulduğu, kurum içi birimlerin bilgisayar ağları ile bütünleşmenin sağlandığ 1 , halkın talep ve şikâyetlerinin alındığı, halkla dijital iletişimin kurulduğu ortamdır (Erdal, 2002: 169).

$\mathrm{Bu}$ tanımlamalardan yola çıkılarak e-Belediye yalnızca belediye hizmetlerinin dijital ortama aktarılması yöntemi değildir. E-Belediye dijital uygulamalarının kullanılması belediyelerin hizmet gücünü ve hızını artıran, açık, denetlenebilir ve hesap verebilir bir idare oluşumuna imkân veren, belediyelerde etkinliği ve verimliliği artıran bir yönetim modelidir (Acılar, 2012: 130). Teknolojide meydana gelen hızlı evrimin en çok etkilediği kuruluşların bașında mahallî idareler gelmektedir. Mahallî idareler, yerel halkın kamusal hizmetlere erişiminde kullandığı ilk yerdir. Bu nedenle halkın mahallî idarelerden beklentileri kent hayatının da etkisiyle çok hızlı değişmektedir. Belediyeler de bu değişime uyabilmek için teknolojik alt yapılarını yenilemekte, internet ve dijital teknolojiden daha çok faydalanmaktadırlar.

Kapsamlı bir faaliyet alanı bulan ve gün geçtikçe daha da büyüyen eBelediye uygulamalarının belediyeler ve halk için pek çok faydası vardır. EBelediye uygulamaları belediyelerin hizmet niteliğinin, etkinliğinin ve faydasının artmasına, vergi tahsilinde kolaylık sağlanmasına, kurumun verimliliğinin ölçümlenmesine, stok ve bilgiye yönelik karar verme sisteminin gelişimine katkıda bulunmaktadır (Çoruh, 2009: 217). Öte yandan e-Belediye vatandaşların nitelikli hizmet almasına, vatandaş odaklı hizmet modelinin gelişimine 7/24 hizmet sunabilmesine, yerel katılımın geliştirilmesine, açık ve hesap verebilir bir idare anlayıșının oluşmasına, savurganlığın engellenmesine, halkın belediyeye olan güveninin sağlanmasına, iyi idare kriterlerinin kamu yönetiminde yaygınlaşmasına da büyük oranda destek olmaktadır (Ulusoy, 2013: 274).

E-Belediye uygulaması mahallî idarelerdeki bürokrasinin azaltılması, yöntemlerin hızlanması, idare bilgi sistemi aracılığıyla bireyin-bireyle, bireyindevletle, devletin-devletle olan işlerinin rahatlatılmasında da önemli bir araçtır (Babacanl1, 2013: 8). E-Belediye uygulamaları kentler tarafindan iki mühim vazifeyi düzenlemektedir. Bunlardan ilki toplu taşıma, ulaşım, emlak, su, doğal gaz ve Beyaz Masa benzeri işlemlerin verilerinin toplanması, kategorize edilmesi ve gerekli olanların gerçekleştirilmesi konusunda fayda sağlamasıdır. İkincisi ise dijital teknoloji sayesinde e-Belediye uygulamalarının vatandaşla belediye arasında köprü vazifesi üstlenmesidir.

E-Belediye ile ilgili ilk uygulamalar Almanya'nın Münih, Hollanda'nın Rotterdam, Danimarka'nın Aarhus, İngiltere'nin Birmingham ve Amerika Birleşik Devletleri'nin Chicago kentlerinde uygulanmıştır. Bu uygulamaların çıkış noktası vatandaş odaklı yönetim anlayışı, yeni mali programlar, halkla etkili iletişim, mahallî vergilerin azaltılması, hizmette yerellik kriterine öncelik tanınması, gönüllülük ve katılıma dayalı bir mahallî idare anlayışının uygulanmasıdır (Şat, 2008: 212). Yerel halka en yakın mahallî idarelerin başında gelen belediyeler, dijital çağ vasıtasıyla etkinliği ve verimliliğini en üst 
safhaya taşımışlardır. Belediyeler, kamusal hizmetlerinin çoğunu e-Belediye uygulamaları aracılığıyla gerçekleştirmektedir. Bu uygulamalar genellikle üç başlık altında toplanmaktadır (Ulusaoy, 2013: 276):

- Basit işlemler (randevu talepleri, mezarlık işlemleri, ihale işlemleri, duyuruları tamamlanan ve devam eden projeler).

- E-tahsilat ve e-beyanname (borç, ceza ve harç ödemeleri, tahsilat, tahakkuk işlemleri, ruhsat işlemleri).

- Çevrim içi başvurular (rayiç değerler, belge sorgulama, şahsi başvuru, Beyaz Masa işlemleri).

Türkiye'de mahallî idareler tarafından en çok kullanılan uyulama ve teknolojiler arasında akıllı kent sistemleri, Beyaz Masa hizmetleri, dijital evrak işlemleri, e-imza, video konferans, coğrafi bilgi sistemi vb. pek çok hizmet yer almaktadır (TASAM, 2006: 40). Bununla beraber mahallî idarelerde bürokratik işlemleri azaltmak, bütçe ve zaman tasarrufu sağlamak için mahallî kamu hizmetlerinin büyük bir çoğunluğu dijital ortama taşınmış ve mahallî idarelerde birçok e-Belediye hizmetleri hayata geçirilmiştir. Yaygın olarak kullanılan eBelediye hizmetleri ise kısaca şöyledir:

- Beyaz Masa işlemleri,

- Çevrim içi tahsilat,

- Arsa rayiç değerleri,

- Sicil arama,

- Beyan bilgileri,

- İnşaat maliyet bedelleri,

- Meclis kararlar1,

- Encümen kararları,

- Çevre temizlik işlemleri,

- Kent bilgi sistemleri,

- İmar durum işlemleri.

Belediyeler, dijital dönüşümle beraber yerel halkın beklenti ve taleplerini yanitlama noktasında kendilerini yenileyerek daha aktif bir yapıya geçmişleridir. $\mathrm{Bu}$ anlamda Türkiye'de nüfus yoğunluğu gözetmeksizin neredeyse tüm belediyeler kendilerine ait internet sitesine ve sosyal medya hesaplarına sahiptirler. Bununla birlikte dijital belediyecilik, belediyelerin internet sitesi üzerinden kendilerini tanıtmasının ve birçok belediye hizmetini internet üzerinden gerçekleştirmesinin ötesinde bir anlam taşımaktadır.

Verilerin bilgisayar ortamına aktarılması ve pek çok hizmetin internet üzerinden sağlanmasıyla gündeme gelen dijital belediyecilik anlayışı, teknolojik unsurların çoğalmasıyla birlikte anlam ve kapsam değişimine uğramıştır (Çapar, 2015: 1).

Tablo 5. Dijital Belediyenin Hedef Alanları

\begin{tabular}{cc}
\hline \multicolumn{2}{c}{ Belediyelerin Dijital Dönüşümü } \\
\hline Entegre İş Akışı & Vatandaş Odaklı Hizmet Anlayışı \\
Şeffaf Veri & Vatandaş Portalları \\
Devamlı Gelişme & Çevrim İçi Belediye Raporlanması \\
Dijital Belediye Hizmetleri & Belediye Web Siteleri ve Uygulamaları \\
\hline
\end{tabular}


Tablo 5'te görüldüğg̈ üzere, belediyelerde dijital dönüşüm pek çok yeniliği beraberinde getirmekle birlikte hem belediyeler hem de vatandaşlar tarafindan önemli değişmeler gerçekleştirmiştir. $\mathrm{Bu}$ değişmeler belediye içerisinde entegre akışı, açık ve şeffaf veri, devamlı kendisini yenileyen gelişmeler ve son olarak da dijital belediye hizmetleri şeklinde görülmektedir. Vatandaş açısından ise vatandaş merkezli hizmet modeline geçilmesi, vatandaş giriş portallarını rahatlıkla kullanabilmesi, çevrim içi olarak belediyeden talep ettiği raporlara kolaylıkla erişebilmesi, e-Belediye ve internet sitesi üzerinden günün her saatinde belediyeye ulaşabilmesidir. Kısaca dijital belediyenin hedef noktası yerel halka kentsel konularda daha hızlı ve konforlu kamusal hizmet sunarak vatandaş katılımını artırmak, bunun yanında belediyenin kendi içerisindeki iş akışını kolaylaştırarak kaliteli hizmet verilmesine imkân sağlamak şeklinde ifade edilebilir.

Bütün bu teknolojik uygulamalar yardımıyla belediye idarelerinin işi hem kolaylaşmakta hem de zorlaşmaktadır. Zorlaşmasının nedeni, teknolojik olanaklardan yararlanmak için daha çok çabaya ve uzmanlığa gereksinim duyulmasıdır. Ayrıca nesnelerin interneti, artırılmış gerçeklik, yeni dijital ve akıllı üretim teknolojileri alıştığımız fiziksel mekânın üstünde yeni bir mekân sunmaktadır. Basitleşmesinin nedeni ise siber mekânda ortaya konan eylemlerin hemen hepsinin dijital hâle gelmesinden dolayı bir yerlerde kaydedilmesidir (Aksu, 2018: 150). Bundan dolayı dijital devrimle beraber mekân algisı dönüşüme uğrayarak yeni bir dijital fiziki mekân gerçekliği meydana gelmiştir.

\section{Sonuc}

Dijital dönüşüm öncesinde Türk kamu yönetim sistemi, vatandaşın kamusal hizmetlere ulaşması noktasında yetersiz kalan kamu yönetim sistemi özellikle 2002 sonrasında kendisini yenileyerek daha canlı bir yapı hâlini almıştır. Dijital devir, kamu sisteminde halka hizmet sunma noktasındaki çalışmalarını hem hızlandırmış hem de herkesin faydalanabileceği biçimde basite indirgemiştir. Kamu yönetim sisteminde daha etkili, açık ve katılımcı bir model oluşturulması amacıyla bilgi-haberleşme teknolojileri arasında büyük önem taşıyan internet ve internet aracılığıyla sağlanan kamusal hizmetlerin yaygınlaştırılması zorunlu görülmüştür. Dijitalleşme sayesinde insanların birbirleriyle internet bağlantılı akıllı cihazlar ile bilgisayarlar üzerinden hızlı ve konforlu iletişim kurması hem özel teşebbüsü hem de kamu yönetimi sisteminde fayda sağlayacağı düşünülmüştür. Dijital uygulamalar kamu görevlileri, kamu kurumları, kamu hizmet araçları vb. pek çok konuda kamu yönetim sisteminde yenileşme meydana getirmiştir.

Dünya çapında dijital değişimlere paralel olarak meydana gelen teknolojik dönüşüm akıllı robotlar, yapay zekâ benzeri etmenler fiziki ortam ile sanal gerçekliliği bütünleştirmeyi vaat etmektedir. Küresel ölçekte dijital dönüşüm ve halkın birbiriyle iletişimi arttıkça kamu idareleri de ya kendisini bu dönüşüme uyduracak ya da bugünkü dijital devre ayak uyduramama riskiyle yüz yüze kalacaktır. Bu bağlamda dünyada meydana gelen dijital dönüşümle beraber, ikili etkileşimler paralelinde kamusal hizmetlerdeki dijital uygulamaların sayısında artış meydana gelmiştir. Kamu kurumlarının hizmet sunumlarında dijital araçları kullanması, bürokrasi ve kırtasiyeciliğin azaltılması, iyi kamu yönetişimi ilkelerinin hayata geçirilip hizmetlerin açık, denetlenebilir, hesap verebilir, etkili ve verimli bir şekilde sunulması, 
hizmetlerin zaman ve maliyetlerinin azaltılmas1, hizmet kalitesini artırarak halkın hayatının kolaylaştırılması ve daha demokratik bir kamu yönetim sisteminin gerçekleştirilebilmesi noktasında önemli fayda sağlayacaktır.

Bu kapsamda teknolojide meydana gelen bu değişmeler internet ve mobil teknolojilerindeki buluşlar ile kamu yönetim algisında da değişime sebep olmuş, halkın kamu kurumlarına gitmeden e-Devlet ve e-Belediye uygulamaları üzerinden işlerini yapabilmelerine imkân sunmuştur. Diğer ülkelerde olduğu gibi Türkiye de e-Devlet ve e-Belediye uygulamalarında çok yol almıştır. Bununla birlikte uygulamaların kamu kurumları arasında farklı yaklaşımlarının olması nedeniyle uygulanabilirliği konusunda tartışmalar devam etmektedir. $\mathrm{Bu}$ yüzden kamu yönetim sistemiyle ilgili kamusal düzeyde planlama, geliştirme ve denetim aşamalarının daha bütüncül ve sürdürülebilir yaklaşımlarla yürütülmesi gereklidir. Ayrıca kamu yönetim sisteminde dijital devrin meydana getirdiği yeniliklerin hissedilebilmesi için teknolojik altyapı bütçe meselelerinin giderilmesi ve düzenli bir biçimde eğitimlerin kamu idarecilerine ve halka verilmesi önem arz etmektedir. Böylece, dijital devrin meydana getirdiği nimetlerin toplumsal hayata uyarlanması kolaylaşmış olacaktır. Bütün haberleşme araçlarını etkili ve verimli kullanabilecek, yenilikleri kovalayabilecek ve sürdürebilecek uzman elemanların bulundurulması ve yetiştirilmesi gerekmektedir.

$\mathrm{Bu}$ çalışma, özellikle Türk kamu yönetim sisteminde ve kamusal hizmetlerin sunulması noktasında dijital dönüşümün boyutlarından olan eDevlet ve e-Belediye uygulamaları üzerinde durmuş ve bu konuda meydana gelen değişimler genel hatlarıyla anlatılmaya çalışılmıştır. Türkiye'deki kamu yönetim sisteminde dijitalleşmenin yansımaları pek çok literatür taraması neticesinde ele alınmıştır. Çalışmada tespit edildiği üzere, kamusal hizmetlerin sunulmasında dijital dönüşüm alan yazınında genel anlamda olumlu yöndedir. $\mathrm{Bu}$ doğrultuda konuyla ilgili özellikle kamusal yarar, kamusal değer ve kamusal fayda çerçevesinde geliştirilecek eleştirisel bakış açılarına ve akademik çalışmalara gereksinim duyulduğu görülmektedir. Bu bağlamda yapılacak akademik çalışmalar dijital tabanlı uygulamaların gelişimi açısından önemli bir rol oynayacaktır. Son olarak Türk kamu yönetim sisteminin bu dijital dönüşüm sürecinde bir kullanıcı, düzenleyici ve bunların arasında bir köprü olarak aldığı değişik vazifeler ve işlevler henüz net olarak saptanmamış ve yeterince çalış1mamıştır. Bu durum, gelecekte yapılacak akademik çalışmaların odak aldığ önemli meselelerden birisi olabilecektir.

Çıkar Çatışması Beyanı / Conflicts of Interest Statement:

Çalışmada çıkar çatışması bulunmamaktadır.

There is no conflict of interest in the study.

Maddi Destek / Financial Support:

$\mathrm{Bu}$ çalışmada herhangi bir fon veya maddi destekten yararlanılmamıştır.

No funding or financial support was used in this study.

Yazar Katkıları / Contribution Rate of the Authors:

Fikir: AK; Tasarım: AK; Veri Toplama: AK; Kaynak Tarama: AK; Analiz ve Yorum: AK; Makalenin Yazımı: AK.

Idea: AK; Design: AK; Data Collecting: AK; Literature Review: AK; Analysis and Discussion: AK; Writing: AK. 
(!) Yazar/yazarlar bu çalışmanın tüm süreçlerinin araştırma ve yayın etiğine uygun olduğunu, etik kurallara ve bilimsel atıf gösterme ilkelerine uyduğunu beyan etmiştir. Aksi bir durumda Medeniyet Araştırmaları Dergisi sorumlu değildir.

(!) The author/authors declared that all processes of this study are in accordance with research and publication ethics, and comply with ethical rules and principles of scientific citation. Otherwise, the Journal of Civilization Studies is not responsible.

\section{Kaynakça}

Acılar, A. (2012). Küçük Şehir Belediyelerinde Web Sitesi ve E-Belediye Kullanımı: Bilecik Belediyesi Örneği. Dumlupınar Üniversitesi Sosyal Bilimler Dergisi, (32), 125-142.

Akcagündüz, E. (2013). Türkiye'de E-Devlet Sistemine Farklı Bir Bakış: EDevlet ve Tasarruf İlişkisi. Doğuş Üniversitesi Dergisi, 127-140.

Aksu, H. (2018). Dijitopya: Dijital Dönüşüm Yolculuk Rehberi, 2. Bask1. Ankara: Pusula Yayınları.

Balc1, A. (2003). E-Devlet: Kamu Yönetiminde Yeni Perspektifler, Firsatlar ve Zorluklar, Kaтu Yönetiminde Çağdaş Yaklaşımlar. Ankara: Seçkin Yayıncilik.

Babacanl1, H. (2013). Bilgi Teknolojileri ve Internetin Bilinçli, Güvenli Kullanımı. Ankara :Telekomünikasyon İletişim Bakanlığı.

Belli, A. (2016). 6360 Sayılı Yasa ile Kapatılan Belde Belediyelerinin Hizmette Etkinlik, Verimlilik ve Temsil Sorunsalı Üzerine Bir Alan Araştırması: Önsen Belediyesi Örneği. Uluslararası Sosyal Araştırmalar Dergisi, 1698-1373.

Bilgi Teknolojileri ve İletişim Kurumu (t.y.). https://internet.btk.gov.tr/istatistikler, Erişim Tarihi: 12.10.2020.

Bulut, Y. (2000). Büyükşehirlerde Katılımlı Yönetimin Hayata Geçirilmesinde Rol Oynayan Etmeler. Muğla Üniversitesi SBE Dergisi, 1, 1-17

Çarkçı, O. (2010). Türkiye'de E-Devlet Uygulamaları Üzerine Bir Araştırma. Süleyman Demirel Üniversitesi Sosyal Bilimler Dergisi, 95-122.

Çoruh, M. (2009). Kent Bilişim Sistemi E-Belediye. XI. Akademik Bilişim Konferansı Bildirileri. Şanlıurfa: Harran Üniversitesi.

Çapar, M. (2015). Dijital Belediyecilik, Blog, https://www.avd.com.tr/blog/349dijital-belediyecilik, Erişim Tarihi: 12.10.2020.

Delibaş, K. (2010). Dünyada ve Türkiye'de E-Devlet Uygulamaları: Türkiye'de E-Demokrasi ve E-Katılım Potansiyellerinin Harekete Geçirilmesi. Sosyoloji Araştırmaları Dergisi, 101-144.

Dijital Dönüşüm Ofisi (t.y.). https://cbddo.gov.tr, Erişim Tarihi: 12.10.2020.

Eren, V. (2011). Belediye Yöneticilerinin Yerel Yönetim Reformları Hakkındaki Algıları. Mustafa Kemal Üniversitesi Sosyal Bilimler Dergisi, 89-111.

Erdal, M. (2002). Elektronik Bilgi Çağında Kamu Yönetimi ve Bir Yerel Yönetim Uygulaması: İstanbul Büyükşehir Belediyesi. 1. Bilgi ve Ekonomi Kongresi içinde. İzmit: Kocaeli Üniversitesi.

Gül, H. (2018). Dijitalleşmenin Kamu Yönetimi ve Politikaları ile Bu Alanlardaki Araştırmalara Etkileri. Yasama Dergisi, 36, 5-26.

Henden, H. (2005). Yerel Yönetimlerin Hizmet Sunumlarındaki Değişim ve EBelediyecilik. Elektronik Sosyal Bilimler Dergisi, 48-46. 
İşler, B. (2005). Elektronik Devletin Boyutları ve Yarattığı Fırsatlar. Süleyman Demirel Üniversitesi Sosyal Bilimler Enstitüsü Dergisi, 35-56.

Karkın, N. (2011). Vilayet ve İl Özel İdare Web Sitelerinde E-Katılım Olgusu. Süleyman Demirel Üniversitesi Sosyal Bilimler Enstitüsü Dergisi, 5580.

Kaya, A. (2017). Dijital Türkiye Projesi Kapsamında Kamu Hizmetlerinin Dönüşümü. Yüzüncü Yıl Üniversitesi Sosyal Bilimler Enstitüsü Dergisi, 1-11.

Kaypak, Ş. (2009). Küreselleşme Sürecinde E-Dönüşüm ve Belediyelere Yansıması. Uluslararası Bilgi, Ekonomi ve Yönetim Kongresi Bildiri Kitabl, 215-234.

Kaypak, Ş. (2010). E-Dönüşüm Sürecinde e-devlet Yapılanması ve Antakya Yansıması. Uluslararası Bilgi, Ekonomi ve Yönetim Kongresi Bildirimler Kitabı. İstanbul: İstanbul Üniversitesi.

Keleş, R. (2006). Yerinden Yönetim ve Siyaset, 5. Bask1. İstanbul: Cem Yayınevi.

Murphy, S. (2018). Digital Transformation: A Municipal Game Changer. Amo Conferance.

Oğurlu, Y. (2010). İdare Hukukunda E-Devlet Dönüşümü ve Dijitalleşen Kamu Hizmeti. İstanbul: XII Levha Yayınları.

Peker, K. (2015). Yerel Yönetimlerde E-Belediyecilik Uygulamaları ve Mobil Uygulamalara Verilen Önem: İstanbul Örneği. 1. Uluslararası Dijital Yaşam Ortamlart (Digital Life Environment) Kongresi. İstanbul: İstanbul Üniversitesi Açık ve Uzaktan Eğitim Fakültesi.

Pektaş, K. (2011). Belediye Hizmetlerinde Bilgi-İletişim Teknolojilerinin Kullanımı ve E-Belediye Uygulamalarındaki Son Gelişmeler: Bir Literatür Taraması. Sosyal Bilimler Dergisi, 65-88.

Şahin, A. (2007). Türkiye'de E-Belediye Uygulamaları ve Konya Örneği. Erciyes Üniversitesi İ.I.B.F. Dergisi, 29.

Şat, N. (2008). Demokrasi İçin Bir Araç: E-Belediye. Yayınlanmamış doktora tezi, Marmara Üniversitesi, İstanbul.

Ulusoy, A. (2013). Trabzon Belediyesi Örneğinde E-Belediyecilik Uygulamalar1: Trabzon. Türk İdaresi Dergisi, 269-284.

Tasam (2006). E-Belediyecilik Kllavuzu Yerel Yönetim Vatandaş Etkileşimi. İstanbul: Tasam Yayınları.

Toprak, Z. (2006). Yerel Yönetimler. 6.Basım, Ankara: Nobel Yayım Dağıtım.

Wearesocial.com (t.y.). https://wearesocial.com/digital-2020, Erişim Tarihi: 12.10.2020.

Yıldız, M. (1999). Yerel Yönetimde Yeni Bir Katılım Kanalı İnternet: ABD'de ve Türkiye'de Elektronik Kamu Bilgi Ağları. Çağdaş Yerel Yönetimler Dergisi, 144-156.

Yıldırım, U. (2004). Bilgi Toplumu Sürecinde Yerel Yönetimlerde EğitimBilişim Teknolojisinden Yararlanma: Türkiye'de E-Belediye Uygulamaları. The Turkish Online Journal of Educational Technology, 49-60.

Yılmaz, V. (2019). Doğu Anadolu Bölgesinde E-Belediyecilik Hizmetlerinin Yerel Halk Tarafindan Kullanım Düzeylerinin Değerlendirilmesi: Bitlis ve Muş Belediyeleri Örnekleri. Ankara: Beta Yayınevi. 